\author{
KATARZYNA ŁOBACZ \\ Uniwersytet Szczeciński, Polska \\ University of Szczecin, Poland \\ JORDAN KLIMEK \\ Uniwersytet Szczeciński, Polska \\ University of Szczecin, Poland

\section{PIOTR NIEDZIELSKI} \\ Uniwersytet Szczeciński, Polska \\ University of Szczecin, Poland
}

\title{
Wpływ dużych firm sektora nowoczesnych usług biznesowych na innowacyjność mikro, małych i średnich przedsiębiorstw - analiza na przykładzie województwa zachodniopomorskiego
}

\section{The Impact of Big Companies from the Modern Business Services Sector on the Innovativeness of Micro-, Small- and Medium Enterprises - Study Based on the West Pomerania Voivodeship}

\begin{abstract}
Streszczenie: Dyskusja dotycząca roli międzynarodowych korporacji, w tym centrów usług, w regionalnych gospodarkach, choć żywa, wciąż oparta jest na szczątkowych argumentach, pomijających wiele efektów, które są związane z występowaniem centrów usług w regionalnych gospodarkach. Celem artykułu jest dodanie argumentów do tej dyskusji poprzez pokazanie efektów zewnętrznych generowanych przez centra usług, które przenikają do regionalnych gospodarek i wpływają na zachowania biznesowe małych i średnich firm. W szczególności wskazany jest wpływ centów usług na innowacyjność MMSP. Przeprowadzona analiza pozwala wnioskować, że rozwój nowoczesnych usług biznesowych ma pozytywny wpływ na akumulację wiedzy w regionie i pozwala lokalnie funkcjonującym podmiotom na czerpanie z niej. Wskazuje się, że małe firmy korzystające z wiedzy pozyskanej w ramach transferu (np. poprzez transfer ludzi) z firm sektora nowoczesnych usług biznesowych osiągają statystycznie lepsze wyniki w zakresie innowacyjności niż te, które z takiej wiedzy nie korzystają. Dotyczy to zarówno wiedzy związanej z kapitałem ludzkim, jak i z kapitałem materialnym, a znaczenie mają bezpośrednie i pośrednie kanały transferu. Analiza przeprowadzona została w oparciu o dane ilościowe pozyskane na podstawie badań wykonanych na próbie reprezentatywnej małych i średnich firm województwa zachodniopomorskiego.
\end{abstract}

\begin{abstract}
Discussion about the role of this sector in regional economies, though alive, is still based on residual arguments, ignoring many effects which are associated with the existence of service centres in regional economies. This article aims to add some more arguments to that discussion, by presenting external effects generated by multinational service centers, which spills over to regional economy and affect business behaviours of small and medium enterprises. In particular, the innovativeness of MSMEs under the impact of these service centres is analysed. Conducted analysis allows to conclude that the development of modern business services has a positive impact on the accumulation of knowledge in a region and allows local entities to make use of that knowledge. It provides evidence that small companies using knowledge gained through the trans-
\end{abstract}


fer (e.g. through the transfer of people) from the companies from the sector of modern business services achieve statistically better results in terms of innovation than those, who do not use that knowledge. This applies to both knowledge related to human capital, as well as physical capital, which is transferred through direct and indirect transfer channels, including agency and linkages. The analysis has been conducted based on quantitative data obtained from the research on the representative sample of small and medium firms located in the West Pomerania Voivodeship.

Słowa kluczowe: centra usług; efekty rozprzestrzeniania się wiedzy; mikro, małe i średnie przedsiębiorstwa; sektor nowoczesnych usług biznesowych

Keywords: centres of services; knowledge spillovers; micro-, small- and medium enterprises; sector of modern business services

Otrzymano: 18 grudnia 2017

Received: 18 December 2017

Zaakceptowano: 9 lipca 2017

Accepted: 9 July 2017

Sugerowana cytacja / Suggested citation:

Łobacz, K., Klimek, J., Niedzielski, P. (2018). Wpływ dużych firm sektora nowoczesnych usług biznesowych na innowacyjność mikro, małych i średnich przedsiębiorstw - analiza na przykładzie województwa zachodniopomorskiego. Prace Komisji Geografii Przemysłu Polskiego Towarzystwa Geograficznego, 32(3), 38-53. https://doi.org/10.24917/20801653.323.3

\section{WSTĘP}

Sektor nowoczesnych usług biznesowych w Polsce od lat intensywnie się rozwija. W raporcie ABSL z roku 2017 można przeczytać następujące stwierdzenie: „Skala i systematyczny wzrost zatrudnienia oraz poszerzanie zakresu działalności firm posiadających w Polsce centra BPO, SSC, IT, R\&D pozwalają na wyszczególnienie kraju w gronie najważniejszych miejsc na globalnej mapie usług dla biznesu". Systematycznie, z roku na rok, rośnie liczba firm należących do tego sektora, podobnie jak wzrasta generowana przez ten sektor liczba miejsc pracy. Podczas gdy wschodnia i centralna Europa należą do regionów, w których w ostatnich latach wystąpiła wysoka intensywność lokalizacji centrów usługowych międzynarodowych korporacji, szczególnie po 2000 roku (Sass, 2011: 53; Myszkowska, 2014), Polska należy do krajów znajdujących się obecnie w czołówce wybieranych lokalizacji (ABSL, 2016).

Dyskusja dotycząca roli dużych firm sektora nowoczesnych usług biznesowych w regionalnych gospodarkach, choć żywa, wciąż jest oparta na szczątkowych argumentach, pomijających wiele efektów, które są związane z występowaniem centrów usług w regionalnych gospodarkach. Chociaż zaobserwowano, że centra nowoczesnych usług biznesowych są źródłem znaczących dla gospodarek efektów zewnętrznych, również w Polsce (np. Borkowska, 2018), niewiele napisano na temat sektora nowoczesnych usług biznesowych jako źródła wiedzy dla regionu i wpływu tej wiedzy na rozwój lokalnych MMSP.

Celem artykułu jest pokazanie wpływu dużych firm zaliczanych do sektora nowoczesnych usług biznesowych, $w$ tym centrów korporacji międzynarodowych, na innowacyjność mikro, małych i średnich przedsiębiorstw w obszarze regionalnym poprzez transfer wiedzy. Innowacyjność mikro, małych i średnich przedsiębiorstw będzie mierzona zaangażowaniem w rozwijanie i wdrażanie nowych produktów. Analiza oparta została na wynikach badań przeprowadzonych na obszarze województwa zachodniopomorskiego w roku 2016, na próbie reprezentatywnej MMSP zarejestrowanych na terenie województwa, z zastosowaniem modelu pomiaru uwzględniającego trzy kanały 
transferu: bezpośredni transfer kapitału, interakcje na poziomie kapitału, transfer pośredni z wykorzystaniem agentury. Uzyskane wyniki sugerują istotny wpływ dużych firm na innowacyjność lokalnych MMSP, występujący nawet w przypadku ograniczonego rozwoju sektora nowoczesnych usług biznesowych w układzie regionalnym ${ }^{1}$.

\section{SEKTOR NOWOCZESNYCH USŁUG BIZNESOWYCH W LOKALNYCH UKŁADACH GOSPODARCZYCH}

\section{Sektor nowoczesnych usług biznesowych - charakterystyka i rola}

Sektor nowoczesnych usług biznesowych tworzą firmy obsługujące w sposób profesjonalny i zaawansowany wybrane procesy biznesowe innych firm. Z punktu widzenia roli, jaką centra usług odgrywają w procesach gospodarczych, należy je zdefiniować jako firmy realizujące zadania związane z ciągłą obsługą procesów biznesowych innych, zwykle dużych firm. Ich rolą jest obsługa procesów, bez których firmy nie są w stanie funkcjonować i których realizacja (sposób realizacji) wpływa na wykonanie pozostałych procesów w firmie. Mogą one obsługiwać wyspecjalizowane rodzaje procesów (lub ich grupę) zaliczane w przedsiębiorstwie do procesów usługowych, jak np. obsługa klienta, logistyka, procesy finansowe, obsługa IT $^{2}$. Outsourcingowane procesy/usługi mają charakter wysoce wystandaryzowany, co oznacza, że do przekazania w outsourcing nadają się szczególnie procesy o charakterze jednorodnym, odbywające się według zasad, które mogą być precyzyjnie zdefiniowane i skodyfikowane ${ }^{3}$.

Oddziaływanie międzynarodowych korporacji, w tym centrów usług, na lokalne gospodarki jest z reguły postrzegane przez pryzmat trzech rodzajów efektów (Navaretti, Venables, 2004; Sass, 2011):

- efektów związanych z rynkiem produktów,

- efektów związanych z rynkiem czynników produkcji,

- efektów związanych z napływem wiedzy i dóbr (spillover effect).

Relatywne znaczenie poszczególnych efektów zależy od wielu czynników, zwłaszcza od natury dokonanych inwestycji przez podmioty zagraniczne, a także od charakterystyki regionu, w którym się one lokują ${ }^{4}$. W literaturze wyeksponowano i poddano analizie zasadnicze grupy efektów, które są związane z wejściem inwestorów zewnętrznych do lokalnych gospodarek ${ }^{5}$. Efekty te mogą mieć charakter pozytywny lub negatywny.

Napływ inwestycji zagranicznych może pozytywnie oddziaływać na rozwój lokalnych firm. Ponieważ następuje on zwykle z krajów bardziej rozwiniętych do tych o słabszym poziomie rozwoju, często pociąga za sobą napływ nowych, nieznanych lub

\footnotetext{
${ }^{1}$ Artykuł powstał w oparciu o badania przeprowadzone w ramach projektu finansowanego ze środków NCN przyznanych na podstawie decyzji nr DEC-2011/03/B/HS4/05890. Szerokie wnioski z badań zaprezentowano w: Niedzielski, Łobacz (2017), a artykuł przedstawia wybrane i pogłębione wnioski tego studium.

${ }^{2}$ Funkcje usługowe nadające się do zewnętrznego wykonania dotyczą względnie heterogenicznej grupy usług, takich jak: usługi informatyczne, prawne, finansowe, księgowe i marketingowe, procesy badawczo-rozwojowe, medyczne oraz kulturowe.

${ }^{3}$ Rodzaj, zakres, koszt, a także jakość świadczonych usług są elementami precyzyjnie określonymi w umowie między świadczeniodawcą a świadczeniobiorcą. Model ten zakłada więc obsługę procesów usługowych w oparciu o najlepsze praktyki rynkowe. Celem nadrzędnym takich centrów staje się zatem nie tylko osiąganie maksymalnej efektywności kosztowej, ale również doskonałości procesowej, przekładających się razem na wzrost satysfakcji klienta wewnętrznego z obsługi procesów wspierających.

${ }^{4}$ Czynniki te $\mathrm{w}$ odniesieniu do Polski opisują raporty przygotowywane regularnie przez ABSL (np. ABSL 2016, ABSL 2017, więcej raportów dostępnych jest na: http://absl.pl/pl/publikacje/).

${ }^{5}$ Efekty te scharakteryzowano szczegółowo w: Niedzielski, Łobacz (2017).
} 
niestosowanych technologii, a także wiedzy i umiejętności, które mogą przyczynić się do podniesienia konkurencyjności lokalnych podmiotów w ujęciu międzyregionalnym. Do tych korzyści, wynikających z obecności międzynarodowych korporacji w regionie, należą trudno obserwowalne efekty zewnętrzne związane $\mathrm{z}$ napływem wiedzy zewnętrznej (knowledge spillovers), pozwalające na rozwój mniejszych firm stykających się z barierą w zakresie tworzenia i pozyskiwania wiedzy.

Wskazuje się tutaj takie aspekty, jak: uczenie się dzięki współpracy (np. poznawanie bardziej zaawansowanych standardów w pracy czy organizacji) i dzięki temu rozwój w kierunku bardziej zaawansowanych działań; poznanie nowych technologii produkcji, praktyk w obszarze marketingu i podejścia do zarządzania, które mogą być zaadaptowane przez lokalne firmy. Nie bez znaczenia jest także dostęp do pracowników, którzy mogą wnieść nową dynamikę rozwoju do lokalnych firm. Istotne dla rozwoju lokalnego jest również powstawanie powiązań pomiędzy firmami lokalnymi i napływowymi, przekładających się często na dostęp do nowych rynków zbytu, oraz pojawianie się nowych okazji rynkowych, np. rozszerzenie działalności wynikające z faktu zostania dostawcą lub podwykonawcą.

W kontekście relacji pomiędzy lokalnymi firmami a dużymi podmiotami wchodzącymi na lokalne rynki literatura wyróżnia dwie zasadnicze kwestie:

- efekty związane bezpośrednio z napływem wiedzy (knowledge spillovers),

- efekty wynikające z tworzenia powiązań pomiędzy firmami (linkages).

Efekty związane z napływem wiedzy zasadniczo stanowią pozytywne efekty zewnętrzne wynikające z obecności korporacji międzynarodowych w lokalnych gospodarkach (Blomström, Kokko, 1997). Wynikają one z naturalnej przewagi wchodzących firm nad firmami lokalnymi (Dunning, 1988) oraz z faktu, że firmy wchodzące nie są w stanie zabezpieczyć w pełni swoich zasobów wiedzy (jest to niemożliwe) lub nie koncentrują się na tym (nie są tym zainteresowane, nie jest to dla nich szczególnie ważne) z uwagi na i tak posiadaną dużą przewagę. Potencjał w zakresie generowania tych efektów wynika zatem z wielkości luki wiedzy, występującej pomiędzy zdolnościami w obszarze wykorzystania technologii, rozwoju kapitału, rozwoju organizacji i technik zarządzania, występującej pomiędzy wchodzącymi firmami a podmiotami lokalnymi (Rugraff, Hansen, 2011).

Lokalne firmy mogą ponadto odnosić korzyści z bliskości funkcjonowania korporacji międzynarodowych pomimo braku bezpośredniej interakcji z nimi lub bardzo ograniczonego jej zakresu. Korzyści te mogą bowiem wynikać z samego faktu znajdowania się we wspólnym otoczeniu konkurencyjnym albo obserwowania realizowanych przez inne podmioty (osoby) działań oraz ich efektów (Rugraff, Hansen, 2011). Udowodniono, że bezpośrednie powiązania (linkages) mogą w ogromnym stopniu przyczynić się do wzmocnienia efektów związanych z napływem wiedzy (spillovers), na co wskazują m.in.: T. Altenburg (2000), J. Scott-Kennel i P. Enderwick (2005), M.W. Hansen i H. Schaumburg-Müller (2006).

\section{Metodyka i podejście badawcze}

W oparciu o wnioski wynikające z przedstawionych powyżej analiz podjęto się określenia rezultatów wynikających z przepływu wiedzy pomiędzy dużymi firmami należącymi do sektora nowoczesnych usług biznesowych a mikro, małymi i średnimi przedsiębiorstwami działającymi w układach regionalnych. W tym celu posłużono się przykładem 
województwa zachodniopomorskiego, co pozwoliło przyjrzeć się wskazanym efektom w regionie o niewielkim poziomie oddziaływania, spowodowanym jego ograniczonym - w porównaniu do innych regionów - udziałem w procesach gospodarczych.

Ze względu na znaczne podobieństwo dużych firm funkcjonujących w ramach sektora nowoczesnych usług biznesowych, niezależnie od ich krajowego i międzynarodowego pochodzenia, wynikające przede wszystkim z podobnego zorientowania na obsługiwane procesy, kumulację wiedzy profesjonalnej związanej z realizowanymi usługami, międzynarodowego zorientowania na klienta, jak również częstych przejęć przez inwestorów zagranicznych (Niedzielski, Łobacz, 2017), przyjęto możliwość analizowania generowanych przez nie efektów zewnętrznych w podobnym układzie.

Analizę przeprowadzono w oparciu o wyniki badań ilościowych zrealizowanych przez zespół badawczy w roku 2016 na próbie reprezentatywnej 1100 mikro, małych i średnich przedsiębiorstw województwa zachodniopomorskiego. Badanie uwzględniało trzy obszary/kanały transferu wiedzy, czyli:

- bezpośredni transfer kapitału (ludzkiego i materialnego) wraz z zakumulowaną w nim wiedzą; dotyczy zarówno osób na rynku pracy, jak i wiedzy związanej z kapitałem materialnym, np. technologiami,

- przepływ wiedzy poprzez interakcje na poziomie kapitału (ludzkiego i materialnego); dotyczy bezpośrednich styczności pomiędzy pracownikami lub pomiędzy pracownikami i kapitałem materialnym, w tym przede wszystkim technologiami; ważnym elementem tych efektów jest przepływ wiedzy związanej z know-how związany z wykorzystywaniem metod zarządzania oraz stosowaniem technologii w określonych procesach,

- przepływ wiedzy poprzez pośrednika (agenta); przepływ wiedzy ma w tym przypadku charakter pośredni i uwzględnia osoby trzecie pośredniczące w przepływie wiedzy pomiędzy firmami i będące nośnikami tej wiedzy, w tym przede wszystkim doradców biznesowych ${ }^{6}$.

W celu określenia rezultatów wynikających z transferu wiedzy posłużono się zmienną odnoszącą się do innowacyjności mikro, małych i średnich firm wynikającej z transferu wiedzy, mierzoną jako liczbę nowych produktów wdrożonych na rynek.

Schemat analizy z wyodrębnionymi i opisanymi wcześniej ścieżkami transferu wiedzy przedstawiono na ryc. 1.

W przypadku struktury wielkości przedsiębiorstw ze względu na liczbę osób zatrudnionych występuje nadreprezentacja małych i średnich podmiotów, co stanowiło celowy zamysł badaczy. Wynikało bowiem z potrzeby uzyskania danych porównawczych odnośnie do zachodzenia badanych zjawisk pomiędzy poszczególnymi kategoriami podmiotów (mikro, małymi i średnimi), co byłoby niemożliwe w przypadku przyjęcia odsetka zgodnego z rozkładem częstości cech w populacji w odniesieniu do wielkości próby badawczej. Pomimo zastosowanego zabiegu nałożenia wagi w próbie struktura wielkości przedsiębiorstw badanych nie odbiega w znaczny sposób od parametrów populacji.

Dobór próby do badania ilościowego uwzględniał następujące parametry: wielkość przedsiębiorstwa (liczba osób zatrudnionych), lokalizacja siedziby przedsiębiorstwa, obszar działalności przedsiębiorstwa. Szczegóły próby zestawiono w tab. 1.

${ }^{6}$ Jak zaobserwowano, doradcy biznesowi świadczący swoje usługi w oparciu o głębokie modele doradztwa mogą w znaczący sposób oddziaływać na procesy rozwojowe firm, w tym na podejmowane przez nie działania innowacyjne (Łobacz, Głodek, Stawasz, Niedzielski, 2016) 
Ryc. 1. Schemat analizy efektów zewnętrznych z wyodrębnionymi ścieżkami transferu wiedzy

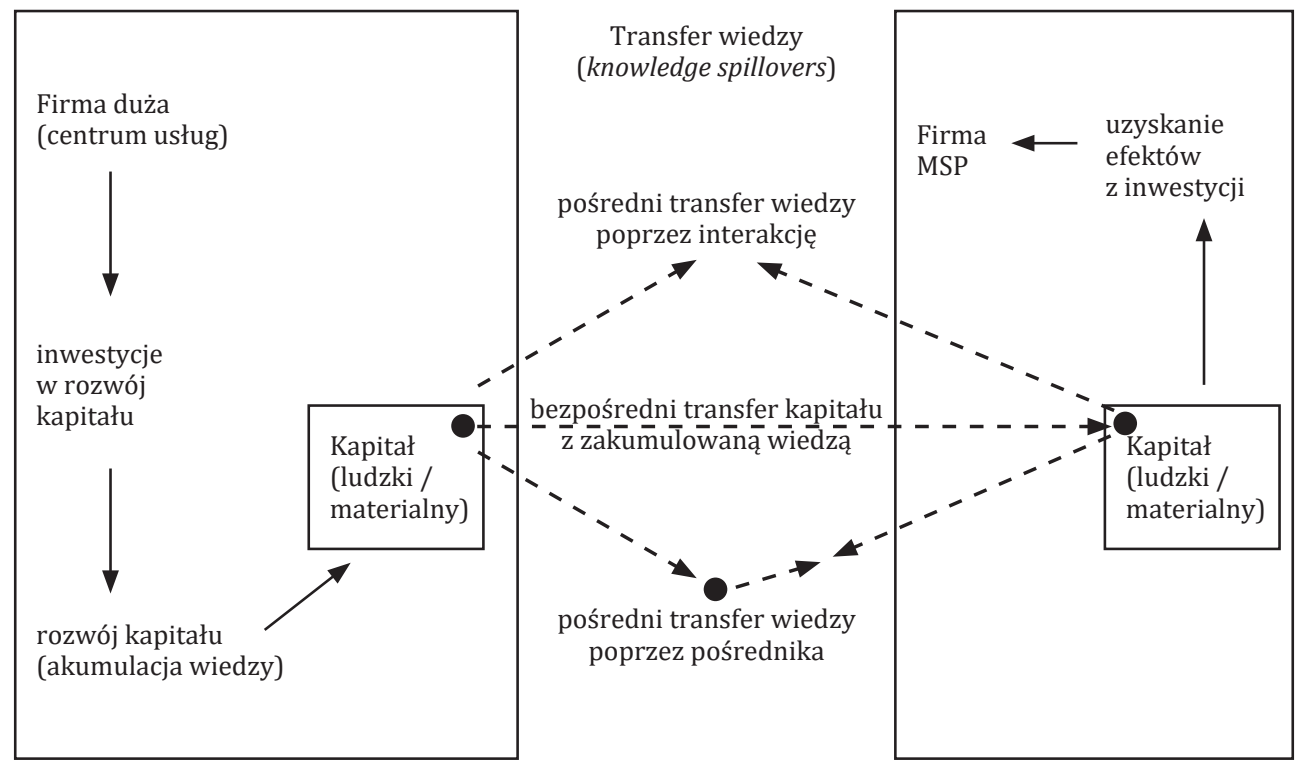

Legenda:

jednostka kapitału

- - - - $\rightarrow$ interakcja na poziomie kapitału

$-\rightarrow \leftarrow$ - kierunek transferu wiedzy związanej z kapitałem

$\longrightarrow$ kierunek działań/procesów związanych z inwestycjami w rozwój kapitału

Źródło: Niedzielski, Łobacz (2017: 142)

Tab. 1. Parametry doboru próby badawczej do badania ilościowego

\begin{tabular}{|l|c|c|}
\hline $\begin{array}{c}\text { Wielkość przedsiębiorstw: liczba } \\
\text { osób zatrudnionych }\end{array}$ & $\begin{array}{c}\text { Odsetek przedsiębiorstw } \\
\text { w województwie } \\
\text { zachodniopomorskim } \\
\text { w 2016 roku }\end{array}$ & $\begin{array}{c}\text { Odsetek przedsiębiorstw } \\
\text { objętych badaniem }\end{array}$ \\
\hline Mikro (0-9 osób) & $96,3 \%$ & $82,3 \%$ \\
\hline Małe (10-49 osób) & $3,0 \%$ & $12,9 \%$ \\
\hline Średnie (50-249 osób) & $0,6 \%$ & $4,8 \%$ \\
\hline Duże (powyżej 250 osób) & $0,1 \%$ & $0,0 \%$ \\
\hline Ogółem & $100,0 \%$ & $100,0 \%$ \\
\hline
\end{tabular}

Źródło: opracowanie własne na podstawie danych GUS

Lokalizacja siedziby przedsiębiorstwa stanowiła podstawowy mechanizm losowania przedsiębiorstw do realizacji pomiaru (poprzez wybór połączeń telefonicznych z przedsiębiorstwami z poszczególnych miejscowości regionu) i odzwierciedlała rozkład liczby przedsiębiorstw $\mathrm{w}$ województwie zachodniopomorskim na poziomie powiatów. Szczegółową strukturę przedstawiono w tab. 2. 
Tab. 2. Struktura próby badawczej w badaniu ilościowym - lokalizacja siedziby przedsiębiorstwa

\begin{tabular}{|c|c|c|}
\hline $\begin{array}{l}\text { Powiaty województwa } \\
\text { zachodniopomorskiego }\end{array}$ & $\begin{array}{c}\text { Odsetek przedsiębiorstw } \\
\text { w województwie } \\
\text { zachodniopomorskim w podziale } \\
\text { na lokalizację }\end{array}$ & $\begin{array}{l}\text { Odsetek przedsiębiorstw objętych } \\
\text { badaniem }\end{array}$ \\
\hline Powiat białogardzki & $2,2 \%$ & $2,2 \%$ \\
\hline Powiat kołobrzeski & $5,7 \%$ & $5,7 \%$ \\
\hline Powiat koszaliński & $3,3 \%$ & $3,3 \%$ \\
\hline Powiat sławieński & $2,7 \%$ & $2,6 \%$ \\
\hline Powiat m. Koszalin & $8,3 \%$ & $8,3 \%$ \\
\hline Powiat choszczeński & $1,9 \%$ & $1,9 \%$ \\
\hline Powiat drawski & $2,7 \%$ & $2,6 \%$ \\
\hline Powiat myśliborski & $3,1 \%$ & $3,1 \%$ \\
\hline Powiat pyrzycki & $1,7 \%$ & $1,7 \%$ \\
\hline Powiat szczecinecki & $3,6 \%$ & $3,6 \%$ \\
\hline Powiat świdwiński & $2,0 \%$ & $2,0 \%$ \\
\hline Powiat wałecki & $2,6 \%$ & $2,6 \%$ \\
\hline Powiat łobeski & $1,5 \%$ & $1,5 \%$ \\
\hline Powiat m. Szczecin & $30,8 \%$ & $30,8 \%$ \\
\hline Powiat goleniowski & $4,0 \%$ & $4,0 \%$ \\
\hline Powiat gryficki & $3,5 \%$ & $3,5 \%$ \\
\hline Powiat gryfiński & $3,9 \%$ & $3,9 \%$ \\
\hline Powiat kamieński & $3,2 \%$ & $3,2 \%$ \\
\hline Powiat policki & $4,8 \%$ & $4,8 \%$ \\
\hline Powiat stargardzki & $5,6 \%$ & $5,5 \%$ \\
\hline Powiat m. Świnoujście & $2,9 \%$ & $2,9 \%$ \\
\hline Ogółem & $100,0 \%$ & $100,0 \%$ \\
\hline
\end{tabular}

Źródło: opracowanie własne na podstawie danych GUS

Struktura przedsiębiorstw uczestniczących w badaniu w zestawieniu z przedsiębiorstwami w województwie zachodniopomorskim również jest zbieżna pod względem obszaru działalności, co oznacza, że przedstawiony w opracowaniu obraz rzeczywistości społeczno-gospodarczej województwa najprawdopodobniej nie odbiega od stanu faktycznego. Odpowiednie porównanie przedstawiono w tab. 3.

Tab. 3. Struktura próby badawczej w badaniu ilościowym - obszar działalności przedsiębiorstwa

\begin{tabular}{|l|c|c|}
\hline \multicolumn{1}{|c|}{ Sekcja; obszar działalności } & $\begin{array}{c}\text { Odsetek przedsiębiorstw } \\
\text { w województwie } \\
\text { zachodniopomorskim } \\
\text { w 2014 roku }\end{array}$ & $\begin{array}{c}\text { Odsetek przedsiębiorstw } \\
\text { objętych badaniem }\end{array}$ \\
\hline Przetwórstwo przemysłowe & $8,0 \%$ & $7,9 \%$ \\
\hline Budownictwo & $12,5 \%$ & $22,9 \%$ \\
\hline $\begin{array}{l}\text { Handel, naprawa pojazdów } \\
\text { samochodowych }\end{array}$ & $23,3 \%$ & $6,5 \%$ \\
\hline $\begin{array}{l}\text { Transport i gospodarka } \\
\text { magazynowa }\end{array}$ & $6,3 \%$ & $7,3 \%$ \\
\hline Obsługa rynku nieruchomości & $7,3 \%$ & \\
\hline
\end{tabular}




\begin{tabular}{|l|r|r|}
\hline $\begin{array}{l}\text { Działalność profesjonalna, } \\
\text { naukowa i techniczna }\end{array}$ & $7,8 \%$ & $8,0 \%$ \\
\hline Pozostała działalność usługowa & $6,1 \%$ & $6,3 \%$ \\
\hline Pozostałe sekcje & $28,7 \%$ & $28,5 \%$ \\
\hline Ogółem & $100,0 \%$ & $100,0 \%$ \\
\hline
\end{tabular}

Źródło: opracowanie własne na podstawie danych GUS

Mając na względzie zgodność kontrolowanych charakterystyk próby z charakterystyką badanej populacji, można uznać, że przyjęta próba spełnia kryteria reprezentatywności dla przeprowadzonego badania.

\section{Oddziaływanie dużych firm sektora nowoczesnych usług biznesowych na innowacyjność mikro, małych i średnich firm}

Innowacyjność firm, w tym szczególnie firm mikro, małych i średnich (Łobacz, 2012) zależy od kapitału wiedzy, na którym firma opiera swoje działania. Wiedza, o różnym charakterze, stanowi podstawę lub źródło działań rozwojowych podmiotów gospodarczych (Łobacz, 2015; Stawasz, Głodek, Łobacz, Niedzielski, 2018). Dlatego efekty zewnętrzne wynikające z przepływu wiedzy stanowią ważną podstawę rozwoju małych i średnich firm.

W tab. 4 przedstawiono porównanie firm, których właściciele mają doświadczenia związane z pracą w korporacjach oraz tych, które nie mają takich doświadczeń - ogółem oraz osobno w centrach usług w odniesieniu do działań firm nakierowanych na wprowadzenie na rynek nowych produktów. Uzyskane wyniki sugerują występowanie efektów wynikających z transferu wiedzy z firm o charakterze korporacyjnym, w tym szczególnie z tych o charakterze usługowym.

Tab. 4. Przedsiębiorstwa, które wprowadziły na rynek nowe produkty, w zależności od doświadczenia właścicieli, zatrudnionych w korporacji lub w centrum usług

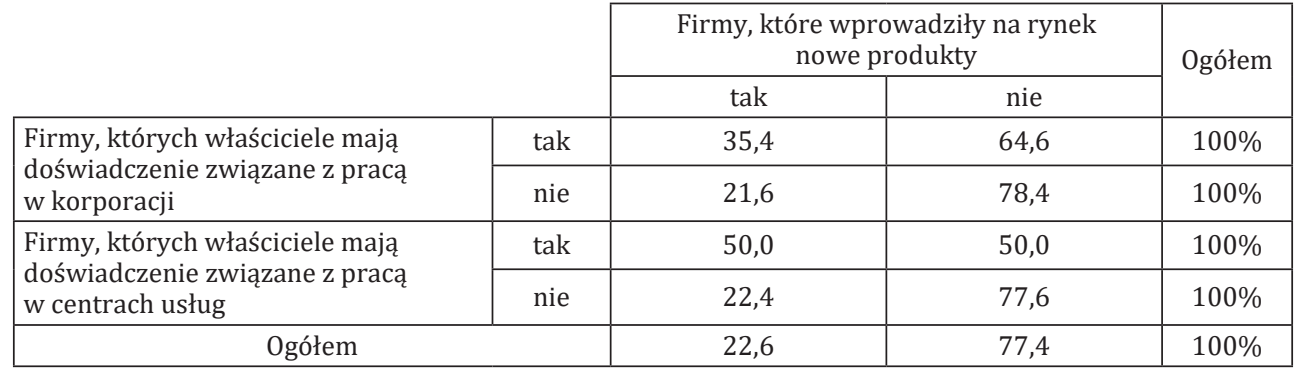

Źródło: opracowanie własne

Z danych wynika, że firmy, których właściciele mają doświadczenie w pracy w centrum usług lub korporacji, częściej wprowadzają na rynek nowe produkty niż te podmioty, których właściciele nie mają tego typu doświadczenia (test Chi kwadrat = 11,097). Pomimo że wskazane zjawisko należy oceniać w kategoriach słabego związku statystycznego (R Pearsona $=-0,104$ ), liczba nowych produktów wprowadzanych na rynek jest większa, gdy osoby miały doświadczenia związane z pracą w korporacji. Ponadto większy odsetek właścicieli zachodniopomorskich firm sektora MMSP, którzy 
mają doświadczenie w pracy w centrach usług, wprowadził na rynek nowe produkty (50\%) niż odsetek tych właścicieli, którzy mają doświadczenie w pracy ogólnie w korporacjach $(35,4 \%)$. Dla porównania, średnio co piąty właściciel przedsiębiorstwa z regionu Pomorza Zachodniego (22,6\%) wprowadził na rynek nowe produkty. Powyżej pięciu nowych produktów wdrożyło 8,7\% firm, które współpracowały z korporacją, a jedynie 4,9\% firm niemających takich doświadczeń.

Podobne zależności pokazuje analiza oddziaływania, jakie wywierają pracownicy o doświadczeniach korporacyjnych na rozwój firm. Dane obrazujące to zjawisko zestawiono w tab. 5.

Tab. 5. Przedsiębiorstwa, które wprowadziły na rynek nowe produkty, w zależności od doświadczenia pracowników, zatrudnionych w korporacji lub w centrum usług

\begin{tabular}{|c|c|c|c|c|}
\hline & & \multicolumn{2}{|c|}{$\begin{array}{c}\text { Firmy, które wprowadziły na rynek nowe } \\
\text { produkty }\end{array}$} & \multirow[t]{2}{*}{ Ogółem } \\
\hline & & tak & nie & \\
\hline \multirow{2}{*}{$\begin{array}{l}\text { Firmy, których pracownicy } \\
\text { mają doświadczenie związane } \\
\text { z pracą w korporacji o określonej } \\
\text { charakterystyce }\end{array}$} & tak & 37,5 & 62,5 & $100 \%$ \\
\hline & nie & 21,2 & 78,8 & $100 \%$ \\
\hline \multirow{2}{*}{$\begin{array}{l}\text { Firmy, których pracownicy mają } \\
\text { doświadczenie związane z pracą } \\
\text { w centrach usług o określonej } \\
\text { charakterystyce }\end{array}$} & tak & 100,0 & 0,0 & $100 \%$ \\
\hline & nie & - & - & $100 \%$ \\
\hline \multicolumn{2}{|l|}{ Ogółem } & 23,0 & 77,0 & $100 \%$ \\
\hline
\end{tabular}

Źródło: opracowanie własne

Wyniki przeprowadzonej analizy przynoszą zaskakujące rezultaty, choć ich interpretacja z uwagi na rozmiar próby powinna być traktowana z pewną ostrożnością. Pokazują one, że zachodniopomorskie firmy sektora MMSP, które zatrudniły pracowników wywodzących się z centrów usług, znacznie częściej wprowadziły na rynek nowe usługi (100\% takich firm) niż podmioty, które zatrudniły pracowników z doświadczeniem pracy w korporacji $(37,5 \%)$. Dla porównania, jedynie co piąta firma z regionu $(23,0 \%)$ wprowadziła na rynek nowe produkty. Sugeruje to, że podmioty gospodarcze zatrudniające pracowników z doświadczeniem pracy w centrach usług znacznie częściej wprowadzają na rynek nowe produkty niż pozostałe przedsiębiorstwa (Chi kwadrat $=11,148)$. Jakkolwiek omówione współwystępowanie należy uznać za bardzo słaby związek statystyczny (R Pearsona $=-0,001$ ) - konieczny do potwierdzenia w dalszych badaniach - wydaje się, że przedstawione ustalenia mogą mieć odzwierciedlenie w rzeczywistości społeczno-gospodarczej.

W odniesieniu do efektów wynikających z wykorzystania i transferu wiedzy związanej z kapitałem materialnym przeanalizowano związek pomiędzy nabyciem przez MMSP technologii od firm o charakterze korporacyjnym a wykorzystaniem do realizacji swoich działań technologii będących w ich posiadaniu. Dane zestawiono w tab. 6 i 7. Wynika z nich, że zachodniopomorskie przedsiębiorstwa, które nabyły maszyny lub urządzenia będące wcześniej w posiadaniu centrów usług, znacznie częściej wprowadzają na rynek nowe produkty (100\%) niż te podmioty gospodarcze, które pozyskały technologie będące wcześniej w posiadaniu korporacji $(57,1 \%)$. Zaobserwowany związek statystyczny (chi kwadrat = 25,496) należy oceniać jako słaby 
(R Pearsona $=-0,132)$, jednak znaczący. Powyższe ustalenie zdaje się potwierdzać fakt, że liczba firm, które nie nabyły maszyn lub urządzeń będących wcześniej w posiadaniu centrów usług lub korporacji i wprowadziły na rynek nowe produkty, nie przekroczyła 22,6\%.

Tab. 6. Przedsiębiorstwa, które wprowadziły na rynek nowe produkty, w zależności od nabycia maszyn lub urządzeń będących wcześniej w posiadaniu korporacji lub centrum usług

\begin{tabular}{|c|c|c|c|c|}
\hline & & \multicolumn{2}{|c|}{$\begin{array}{l}\text { Firmy, które wprowadziły na rynek } \\
\text { nowe produkty }\end{array}$} & \multirow[t]{2}{*}{ Ogółem } \\
\hline & & tak & nie & \\
\hline \multirow{2}{*}{$\begin{array}{l}\text { Firma nabyła maszyny lub urządzania } \\
\text { będące wcześniej w posiadaniu korporacji }\end{array}$} & tak & 57,1 & 42,9 & $100 \%$ \\
\hline & nie & 22,3 & 77,7 & $100 \%$ \\
\hline \multirow{2}{*}{$\begin{array}{l}\text { Firma nabyła maszyny lub urządzania } \\
\text { będące wcześniej w posiadaniu centrum } \\
\text { usług }\end{array}$} & tak & 100,0 & 0,0 & $100 \%$ \\
\hline & nie & 22,5 & 77,5 & $100 \%$ \\
\hline \multicolumn{2}{|l|}{ Ogółem } & 22,6 & 77,4 & $100 \%$ \\
\hline
\end{tabular}

Źródło: opracowanie własne

Tab. 7. Przedsiębiorstwa, które wprowadziły na rynek nowe produkty w zależności od wykorzystywania do swoich działań maszyn lub urządzeń będących w posiadaniu korporacji lub Centrum Usług

\begin{tabular}{|c|c|c|c|c|}
\hline & & \multicolumn{2}{|c|}{$\begin{array}{l}\text { Firmy, które wprowadziły na rynek nowe } \\
\text { produkty }\end{array}$} & \multirow[t]{2}{*}{ Ogółem } \\
\hline & & tak & nie & \\
\hline \multirow{2}{*}{$\begin{array}{l}\text { Firma wykorzystywała do swoich } \\
\text { działań maszyny lub urządzania będące } \\
\text { w posiadaniu korporacji }\end{array}$} & tak & 48,4 & 51,6 & $100 \%$ \\
\hline & nie & 22,1 & 77,9 & $100 \%$ \\
\hline \multirow{2}{*}{$\begin{array}{l}\text { Firma wykorzystywała do swoich } \\
\text { działań maszyny lub urządzania będące } \\
\text { w posiadaniu centrum usług }\end{array}$} & tak & 100,0 & 0,0 & $100 \%$ \\
\hline & nie & 22,6 & 77,4 & $100 \%$ \\
\hline \multicolumn{2}{|l|}{ Ogółem } & 22,6 & 77,4 & $100 \%$ \\
\hline
\end{tabular}

Źródło: opracowanie własne

Podobnie zachodniopomorskie przedsiębiorstwa, które wykorzystywały do swoich działań maszyny lub urządzenia centrów usług, znacznie częściej wprowadzały na rynek nowe produkty (100\%) niż te podmioty gospodarcze, które wykorzystywały do swoich działań technologie korporacji $(48,4 \%)$. Z kolei liczba firm, które nie wykorzystywały do swoich działań maszyn lub urządzeń centrów usług lub korporacji i wprowadziły na rynek nowe produkty, nie przekroczyła 22,6\%.

Innym aspektem jest nabycie kapitału o charakterze materialnym przez MMSP wspólnie z dużymi podmiotami. Dane przedstawiające zależność pomiędzy takim nabyciem a wdrożeniem na rynek nowych produktów zestawiono w tab. 8.

Dane te pokazują, że zachodniopomorskie przedsiębiorstwa, które nabyły maszyny lub urządzenia wspólnie z centrami usług, znacznie częściej wprowadzają na rynek nowe produkty (100\%) niż te podmioty gospodarcze, które pozyskały technologie będące wcześniej w posiadaniu korporacji $(72,7 \%)$.

Jeśli zatem bezpośredni transfer kapitału z centrów usług do lokalnych małych i średnich przedsiębiorstw wydaje się mieć tak znaczący wpływ na rozwój sektora MMSP, pozostaje pytanie, jakie oddziaływanie ma pośredni transfer wiedzy poprzez 
interakcje. Bazowych informacji na ten temat dostarcza nam analiza tab. 9, przedstawiająca odsetek przedsiębiorstw, które wprowadziły na rynek nowe produkty, w zależności od doświadczenia współpracy z korporacją lub centrum usług.

Wynika z niej, że firmy z regionu Pomorza Zachodniego, które współpracowały z centrami usług $(66,7 \%)$, znacznie częściej wprowadzały na rynek nowe produkty niż podmioty współpracujące z korporacjami (41,4\%). Współwystępowanie dwóch zmiennych, czyli współpracy z centrami usług i wprowadzenia na rynek nowych produktów (Chi kwadrat = 38,107), wskazuje na istnienie słabego związku statystycznego (R Pearsona $=-0,192$ ). Dla porównania, odsetek zachodniopomorskich firm, które nie współpracowały z korporacjami lub centrami usług, a które wprowadziły na rynek nowe produkty, nie przekracza $22,6 \%$. Pogłębiona analiza danych empirycznych wskazuje także, że zdecydowanie większą liczbę innowacji wprowadziły właśnie te firmy, które współpracowały z centrami usług lub korporacjami, niż podmioty bez takiego doświadczenia.

Tab. 8. Przedsiębiorstwa, które wprowadziły na rynek nowe produkty, w zależności od nabycia maszyn lub urządzeń wspólnie z korporacją lub centrum usług

\begin{tabular}{|c|c|c|c|c|}
\hline & & \multicolumn{2}{|c|}{$\begin{array}{l}\text { Firmy, które wprowadziły na rynek nowe } \\
\text { produkty }\end{array}$} & \multirow{2}{*}{ Ogółem } \\
\hline & & tak & nie & \\
\hline \multirow{2}{*}{$\begin{array}{l}\text { Firma nabyła maszyny lub urządzania } \\
\text { wspólnie z korporacją }\end{array}$} & tak & 72,2 & 27,8 & $100 \%$ \\
\hline & nie & 21,8 & 78,2 & $100 \%$ \\
\hline \multirow{2}{*}{$\begin{array}{l}\text { Firma nabyła maszyny lub urządzania } \\
\text { wspólnie z centrum usług }\end{array}$} & tak & 100,0 & 0,0 & $100 \%$ \\
\hline & nie & 22,6 & 77,4 & $100 \%$ \\
\hline \multicolumn{2}{|l|}{ Ogółem } & 22,6 & 77,4 & $100 \%$ \\
\hline
\end{tabular}

Źródło: opracowanie własne

Tab. 9. Przedsiębiorstwa, które wprowadziły na rynek nowe produkty, w zależności od doświadczenia współpracy z korporacją lub centrum usług

\begin{tabular}{|c|c|c|c|c|}
\hline & & \multicolumn{2}{|c|}{$\begin{array}{l}\text { Firmy, które wprowadziły na rynek nowe } \\
\text { produkty }\end{array}$} & \multirow[t]{2}{*}{ Ogółem } \\
\hline & & tak & nie & \\
\hline \multirow{2}{*}{$\begin{array}{l}\text { Firmy, które współpracowały } \\
\text { z korporacjami }\end{array}$} & tak & 41,4 & 58,6 & $100 \%$ \\
\hline & nie & 19,0 & 81,0 & $100 \%$ \\
\hline \multirow{2}{*}{$\begin{array}{l}\text { Firmy, które współpracowały } \\
\text { z centrami usług }\end{array}$} & tak & 66,7 & 33,3 & $100 \%$ \\
\hline & nie & 22,2 & 77,8 & $100 \%$ \\
\hline \multicolumn{2}{|l|}{ Ogółem } & 22,6 & 77,4 & $100 \%$ \\
\hline
\end{tabular}

Źródło: opracowanie własne

Uszczegółowieniem tej analizy jest analiza danych, w których wyodrębniono spośród wszystkich form współpracy te interakcje, które związane były z wykorzystaniem maszyn, urządzeń, oprogramowania, co wskazywałoby na pośredni transfer wiedzy związanej z kapitałem materialnym (tab. 10). 
Tab. 10. Przedsiębiorstwa, które wprowadziły na rynek nowe produkty, w zależności od doświadczenia współpracy z korporacją lub centrum usług, związanej z wykorzystaniem maszyn, urządzeń, oprogramowania itp.

\begin{tabular}{|c|c|c|c|c|}
\hline & & \multicolumn{2}{|c|}{$\begin{array}{l}\text { Firmy, które wprowadziły na rynek } \\
\text { nowe produkty }\end{array}$} & \multirow[t]{2}{*}{ Ogółem } \\
\hline & & tak & nie & \\
\hline \multirow{2}{*}{$\begin{array}{l}\text { Firmy, które współpracowały } \\
\text { z korporacjami i była to współpraca } \\
\text { związana z wykorzystaniem maszyn, } \\
\text { urządzeń, oprogramowania itp. }\end{array}$} & tak & 46,3 & 53,7 & $100 \%$ \\
\hline & nie & 37,5 & 62,5 & $100 \%$ \\
\hline \multirow{2}{*}{$\begin{array}{l}\text { Firmy, które współpracowały z centrami } \\
\text { usług i była to współpraca związana } \\
\text { z wykorzystaniem maszyn, urządzeń, } \\
\text { oprogramowania itp. }\end{array}$} & tak & 41,7 & 58,3 & $100 \%$ \\
\hline & nie & 21,6 & 78,4 & $100 \%$ \\
\hline
\end{tabular}

Źródło: opracowanie własne

Z przedstawionych danych wynika, że wpływ technologii i wiedzy technologicznej na wprowadzenie na rynek nowych produktów przez zachodniopomorskie firmy wydaje się być mniejszy, chociaż nie bez znaczenia. Firmy z regionu Pomorza Zachodniego, które współpracowały z centrami usług z wykorzystaniem maszyn, urządzeń, oprogramowania itp. (41,7\%), nieco rzadziej wprowadzały na rynek nowe produkty niż podmioty współpracujące z korporacjami z wykorzystaniem technologii $(46,3 \%)$. Przedstawione dane stanowią sumaryczne wartości dla różnych rodzajów (poziomów) współpracy, przede wszystkim realizacji wspólnych projektów i zamawiania usług w centrach usług lub korporacji.

Ponieważ na transfer wiedzy w małych przedsiębiorstwach mogą mieć także silny wpływ kontakty nieformalne, dodatkowo przeanalizowano udział firm, które wprowadziły na rynek nowe produkty, w zależności od utrzymywania przez właścicieli lub pracowników relacji z osobami zatrudnionymi w korporacjach lub centrach usług. Uzyskane wyniki przedstawiono w tab. 11.

Tab. 11. Udział firm, które wprowadziły na rynek nowe produkty, w zależności od utrzymywania przez właścicieli lub pracowników relacji z osobami zatrudnionymi w korporacjach lub centrach usług

\begin{tabular}{|c|c|c|c|c|}
\hline & & \multicolumn{2}{|c|}{$\begin{array}{l}\text { Firmy, które wprowadziły na rynek } \\
\text { nowe produkty }\end{array}$} & \multirow[t]{2}{*}{ Ogółem } \\
\hline & & tak & nie & \\
\hline \multirow{2}{*}{$\begin{array}{l}\text { Firmy, których właściciele lub } \\
\text { pracownicy pozostawali w relacjach } \\
\text { z osobami zatrudnionymi } \\
\text { w korporacjach lub centrach usług }\end{array}$} & tak & 39,6 & 60,4 & $100 \%$ \\
\hline & nie & 19,5 & 80,5 & $100 \%$ \\
\hline \multicolumn{2}{|l|}{ Ogółem } & 22,6 & 77,4 & $100 \%$ \\
\hline
\end{tabular}

Źródło: opracowanie własne

Wskazują one, że regionalne przedsiębiorstwa sektora MSP, których właściciele lub pracownicy są w stałych relacjach interpersonalnych z przedstawicielami centrów usług lub korporacji, znacznie częściej wprowadzają na rynek nowe produkty $(39,6 \%)$ niż podmioty, których kadra nie utrzymuje tego typu relacji $(19,5 \%)$. Wskazany związek statystyczny (Chi kwadrat $=31,693$ ) należy oceniać jako słaby (R Pearsona = -0,119), jednak w kontekście ogólnej liczby zachodniopomorskich przedsiębiorstw, które wprowadziły na rynek nowe produkty $(22,6 \%)$, wydaje się on nie bez znaczenia. 
Dalej wyniki przeprowadzonych badań pokazują, że znaczenie dla rozwoju firm mają także formalne kanały transferu wiedzy, takie jak szkolenia, warsztaty, konferencje, wizyty studyjne. Bliskość geograficzna, wynikająca z osiedlania się dużych podmiotów w określonych regionach, pozwala zwiększyć prawdopodobieństwo uczestnictwa w takich formalnych spotkaniach przedstawicieli firm sektora MSP. Jak obrazują to dane przedstawione w tab. 12 i 13, firmy z próby województwa zachodniopomorskiego, które brały udział w warsztatach, seminariach, konferencjach itp. z przedstawicielami centrów usług lub korporacji, znacznie częściej wprowadzały na rynek nowe produkty $(42,2 \%)$ niż pozostałe podmioty gospodarcze $(22,6 \%)$. Wskazany związek statystyczny (Chi kwadrat $=42,586)$ należy oceniać jako słaby (R Pearsona $=-0,139)$, jednak znaczący w kontekście liczby firm, które nie brały udziału we wspomnianych wydarzeniach z udziałem przedstawicieli centrów usług lub korporacji, a wprowadziły na rynek nowe produkty $(18,6 \%)$.

Tab. 12. Przedsiębiorstwa, które wprowadziły na rynek nowe produkty, w zależności od udziału ich właścicieli lub pracowników w warsztatach, szkoleniach, konferencjach, w których głos zajmowały osoby zatrudnione w korporacjach lub centrach usług

\begin{tabular}{|c|c|c|c|c|}
\hline & & \multicolumn{2}{|c|}{$\begin{array}{c}\text { Firmy, które wprowadziły na rynek nowe } \\
\text { produkty }\end{array}$} & \multirow[t]{2}{*}{ Ogółem } \\
\hline & & tak & nie & \\
\hline $\begin{array}{l}\text { Firmy, których właściciele } \\
\text { lub pracownicy uczestniczyli } \\
\text { w warsztatach, szkoleniach, } \\
\text { konferencjach itp. }\end{array}$ & \multirow{2}{*}{ tak } & 42,2 & 57,8 & $100 \%$ \\
\hline $\begin{array}{l}\text { w tym: związanych z wykorzystaniem } \\
\text { maszyn, urządzeń, oprogramowania } \\
\text { itp. }\end{array}$ & & 46,4 & 53,6 & $100 \%$ \\
\hline $\begin{array}{l}\text { Firmy, których właściciele lub } \\
\text { pracownicy nie uczestniczyli } \\
\text { w warsztatach, szkoleniach, } \\
\text { konferencjach itp. }\end{array}$ & nie & 18,6 & 81,4 & $100 \%$ \\
\hline \multicolumn{2}{|l|}{ Ogółem } & 22,6 & 77,4 & $100 \%$ \\
\hline
\end{tabular}

Źródło: opracowanie własne

Tab. 13. Przedsiębiorstwa, które wprowadziły na rynek nowe produkty, w zależności od udziału ich właścicieli lub pracowników w wizytach studyjnych z osobami zatrudnionymi w korporacjach lub centrach usług

\begin{tabular}{|c|c|c|c|c|}
\hline & & \multicolumn{2}{|c|}{$\begin{array}{l}\text { Firmy, które wprowadziły na rynek nowe } \\
\text { produkty }\end{array}$} & \multirow{2}{*}{ Ogółem } \\
\hline & & tak & nie & \\
\hline $\begin{array}{l}\text { Firmy, których właściciele lub } \\
\text { pracownicy uczestniczyli w wizytach } \\
\text { studyjnych }\end{array}$ & \multirow{2}{*}{ tak } & 44,6 & 55,4 & $100 \%$ \\
\hline $\begin{array}{l}\text { w tym: związanych z wykorzystaniem } \\
\text { maszyn, urządzeń, oprogramowania } \\
\text { itp. }\end{array}$ & & 42,3 & 57,7 & \\
\hline $\begin{array}{l}\text { Firmy, których właściciele lub } \\
\text { pracownicy nie uczestniczyli } \\
\text { w wizytach studyjnych }\end{array}$ & nie & 20,8 & 79,2 & $100 \%$ \\
\hline \multicolumn{2}{|l|}{ Ogółem } & 22,6 & 77,4 & $100 \%$ \\
\hline
\end{tabular}

Źródło: opracowanie własne 
Podobnie firmy z województwa zachodniopomorskiego, które wzięły udział w wizytach studyjnych w centrach usług lub korporacjach, znacznie częściej wprowadzały na rynek nowe produkty $(44, \wedge \%)$ niż podmioty gospodarcze, które nie brały udziału w tego typu przedsięwzięciach (20,8\%). Wskazany związek statystyczny (Chi kwadrat $=19,925)$ należy oceniać jako słaby ( $\mathrm{R}$ Pearsona $=-0,054)$, jednak w kontekście ogólnej liczby firm, które wprowadziły na rynek innowacje $(22,6 \%)$, wydaje się to być bardzo istotnym przypuszczeniem. Warto zaznaczyć, że w przypadku firm z regionu wpływ technologii nie powoduje zwiększenia intensywności wprowadzania na rynek innowacji, czyli liczba firm, które nie wzięły udziału w wizytach studyjnych z wykorzystaniem technologii i wprowadziły na rynek nowe produkty, nie przekroczyła 42,3\%. Powyższe zdaje się potwierdzać przypuszczenie dotyczące częstszego przejawiania postaw proinnowacyjnych przez osoby, które miały doświadczenie udziału w wizytach studyjnych w centrach usług lub korporacjach, w tym z wykorzystaniem technologii.

\section{ZAKOŃCZENIE}

Przeprowadzona analiza pozwala wnioskować, że rozwój nowoczesnych usług biznesowych ma pozytywny wpływ na akumulację wiedzy w regionie i pozwala czerpać z niej lokalnie funkcjonującym podmiotom. Dotyczy to zarówno wiedzy związanej z zaawansowanym zarządzaniem procesowym, jak i wiedzy merytorycznej związanej bezpośrednio z procesem świadczenia usługi czy też z wykorzystaniem w tym procesie zaawansowanych technologii.

Wyniki badań wskazują, że mikro, małe i średnie firmy korzystające z wiedzy pozyskanej w ramach transferu (np. poprzez transfer ludzi) z firm sektora nowoczesnych usług biznesowych osiągają statystycznie lepsze wyniki w zakresie innowacyjności niż te, które z takiej wiedzy nie wykorzystują. Zależność taka występuje w przypadku wszystkich trzech analizowanych kanałów przepływu wiedzy, czyli bezpośredniego transferu kapitału, interakcji występujących na poziomie kapitału oraz transferu pośredniego z wykorzystaniem agentury.

Chociaż efekty zewnętrzne wynikające z bezpośredniego transferu kapitału materialnego wydają się mieć charakter bardziej finansowy i związane są przede wszystkim z obniżeniem kosztów pozyskiwania kapitału (por. Niedzielski, Łobacz, 2017), to jednak pokazana zależność, wynikająca z przeprowadzonych badań, wydaje się bardzo ciekawa poznawczo. Można z tego wnosić, że prawdopodobnie transfer kapitału niesie ze sobą pewien element współpracy, szczególnie w odniesieniu do relacji mikro, mała lub średnia firma - centrum usług, i tym samym dochodzi do przeniesienia pewnego know-how ważnego dla rozwoju firm w sektorze, co nie ma z taką intensywnością miejsca w przypadku pozostałych firm o charakterze korporacyjnym. Jednak przypuszczenie to wymaga dalszego potwierdzenia i może być ciekawym punktem wyjścia dalszych badań.

Można ponadto wnioskować, że styczność biznesowa i jakakolwiek forma współpracy z korporacjami lub centrami usług najprawdopodobniej pozwalają na zdobycie wiedzy cennej z punktu widzenia wytworzenia przewagi konkurencyjnej, a w szczególności realizacji działań rozwojowych. Wydaje się zatem, że aby podnieść poziom innowacyjności przedsiębiorstw sektora MMSP, polityka regionalna mogłaby wpierać inicjowanie współpracy tego typu firm z podmiotami o charakterze korporacyjnym, w tym z centrami usług. Jednak w przypadku centrów usług współpraca ta niekoniecznie musi 
być związana z wykorzystaniem kapitału materialnego. Wskazują na to wyniki analizy danych, w których wyodrębniono ze wszystkich form współpracy interakcje związane z wykorzystaniem maszyn, urządzeń i oprogramowania, sugerując pośredni transfer wiedzy związanej bardziej z kapitałem materialnym.

Wydaje się także, że utrzymywanie stałych relacji z osobami, które są zatrudnione w przedsiębiorstwach o charakterze korporacyjnym lub centrach usług, może przyczyniać się do zdobycia wiedzy proinnowacyjnej, pozwalającej na wytworzenie przewagi konkurencyjnej. Konieczne jednak wydaje się przeprowadzenie dalszych, pogłębionych badań w tym zakresie, które pozwolą na ustalenie formy i charakteru tychże relacji i ich znaczenia dla kreowania pomysłów biznesowych i sposobów podejmowania decyzji w obszarze rozwoju przedsiębiorstw.

\section{Literatura \\ References}

ABSL (2016). Europe’s Business Services Destinations. A journey across 10 countries and 20 cities. Pozyskano z http://abslreport.com/

Altenburg, T. (2000). Linkages and Spillovers between Transnational Corporations and Small and Medium-Sized Enterprises in Developing Countries - Opportunities and Policies. W: UNCTAD (ed.) .MNC-SME Linkages for Development. Issues -experiences - best practices. Proceedings of the Special Round on MNCS, SMEs and Development. Geneva: UNCTAD X, 15 February, 3-61, Bangkok, United Nations.

Blomström, M., Kokko, A. (1997). The Impact of Foreign Investment on Host Countries: A Review of the Empirical Evidence. World Bank Policy Research Working Paper 1745. New York: World Bank.

Borkowska, A. (2018). Wpływ outsourcingu na wybrane aspekty rozwoju ekonomicznego na przykładzie miasta Krakowa. International Entrepreneurship. Przedsiębiorczość Międzynarodowa, 4(1), 49-60.

Dunning, J.H. (1988). The Eclectic Paradigm of International Production: A Restatement and Some Possible Extensions. Journal of International Business Studies, 19(1), 1-31.

Hansen, M.W., Schaumburg-Müller, H. (eds.) (2006). Transnational Corporations and Local Firms in Developing Countries - Linkages and Upgrading. Copenhagen: Copenhagen Business School Press.

Łobacz, K. (2012). Koncepcja oceny procesu komercjalizacji przedsięwzięć gospodarczych w akademickich inkubatorach przedsiębiorczości. Szczecin: rozprawa doktorska, maszynopis powielony.

Łobacz, K. (2015). Źródła wiedzy warunkującej innowacyjne działania przedsiębiorcze -konsekwencje dla sterowania kierunkami rozwoju systemów gospodarczych. Nierówności Społeczne a Wzrost Gospodarczy, 41.

Łobacz, K., Głodek, P., Stawasz, E., Niedzielski, P. (2016). Utilisation of Business Advice in Small Innovative Firms: the Role of Trust and Tacit Knowledge. Entrepreneurial Business and Economics Review, 4(2), 117-138.

Myszkowska, M. (2014). The Scale and Characteristics of Services Offshoring in the Visegrád Countries. Entrepreneurial Business and Economics Review, 2(3), 33-46.

Navaretti, G.B., Venables, A.J. (2004). Multinational Firms in the World Economy. Princeton: Princeton University Press.

Niedzielski, P., Łobacz, K. (red.) (2017). Centra usług $w$ układach regionalnych. Szczecin: Wydawnictwo Naukowe Uniwersytetu Szczecińskiego.

Rugraff, E., Hansen, M.W. (2011). Multinational corporations and local firms in emerging economies. An Introduction. W: E. Rugraff, M.W. Hansen (ed.). Multinational Corporations and Local Firms in Emerging Economies. Amsterdam: Amsterdam University Press.

Sass, M. (2011). The impact of foreign direct investment in business services on the local economy. The case of Hungary. W: Multinational Corporations and Local Firms in Emerging Economies. E. Rugraff, M.W. Hansen (ed.). Amsterdam: Amsterdam University Press. 
Scott-Kennel, J., Enderwick, P. (2005). FDI and Inter-Firm Linkages: Exploring the Black Box of the Investment Development Path. Transnational Corporations, 14(1), 13-23.

Stawasz, E., Głodek, P., Łobacz, K., Niedzielski, P. (2018). Development of competitive advantage of small innovative firm - the role of use and utilisation of business advice. The Business \& Management Review, 8(3), 82-93.

Katarzyna Łobacz, dr, pracownik naukowy, autor książek i artykułów z obszaru innowacyjności, transferu i komercjalizacji wiedzy, przedsiębiorczości akademickiej, rozwoju kompetencji. Doświadczona w realizacji projektów badawczych, w tym w zespołach międzynarodowych. Silnie ukierunkowana na praktyczne zastosowanie wiedzy w postaci analiz wdrożeniowych, rozwoju ośrodków wsparcia innowacyjnej przedsiębiorczości, kierowania rozwojem karier studenckich itp.

Katarzyna Łobacz, Ph.D., university professor, author of academic publications, especially in the field of innovation, knowledge transfer and commercialisation, academic entrepreneurship, competence-based development. Manager of numerous research projects. Places strong emphasis on practical applications of knowledge through expertise works, development of centres supporting innovation and entrepreneurship, development of students carrier pathways, etc.

\title{
Adres/address:
}
Uniwersytet Szczeciński
Wydział Zarządzania i Ekonomiki Usług
Katedra Efektywności Innowacji
ul. Cukrowa 8, 71-004 Szczecin, Polska
e-mail: katarzyna.lobacz@wzieu.pl

Jordan Klimek, mgr, socjolog, badacz kultury w nurcie teorii krytycznej, rozwijający socjologię stosowaną dla potrzeb otoczenia gospodarczego. Autor wielu ekspertyz, analiz, wdrożeń itp.

Jordan Klimek, M.Sc., sociologist, researcher in the field of critical theory of culture, involved in the development of applied economics for economic environment. Author or many analyses, practical applications and expertise work.

\section{Adres/address:}

\author{
Uniwersytet Szczeciński \\ Wydział Zarządzania i Ekonomiki Usług \\ Katedra Efektywności Innowacji \\ ul. Cukrowa 8, 71-004 Szczecin, Polska \\ e-mail: jordan.klimek@wzieu.pl
}

Piotr Niedzielski, prof., pracownik naukowy, doświadczony badacz, szczególnie w obszarze innowacji usługowych, oceny projektów inwestycyjnych, innowacji w sektorze TSL; doświadczony konsultant firm i specjalista w obszarze komercjalizacji wiedzy z silnym naciskiem na rozwój regionalny. Doświadczony w zarządzaniu małymi i dużymi organizacjami, w tym firmami oraz uczelniami wyższymi.

Piotr Niedzielski, Ph.D./professor, university professor, experienced in research, especially in the field of service innovation, investment project appraisal, innovation in the TSL sector; experienced in consultancy and commercialisation of knowledge with strong focus on regional development. Experienced in small and big organisation management (CEO in many companies, Head of Schools).

\section{Adres/address:}

\author{
Uniwersytet Szczeciński \\ Wydział Zarządzania i Ekonomiki Usług \\ ul. Cukrowa 8, 71-004 Szczecin, Polska \\ e-mail: piotr.niedzielski@wzieu.pl
}

